Vesna Damnjanović, Ivana Mijatović

\title{
Student Perception Of Benefits From Being Engaged In International Case Study Competitions
}

DOI: 10.7595/management.fon.2017.0017

\begin{abstract}
The main aim of this research paper is to present experience of the students from Serbia who participated in international business case competitions. The findings indicate the six main benefits for students at case competitions, as follows: skills improvement, knowledge, contacts, self-realization, employment opportunity and the role of mentor. Additionally, we identified some perceived advantages of domestic students compared to colleagues/students from developed countries: presentation, preparation for competition, creativity, multidisciplinary approach to problems and teamwork, while the perceived advantages of colleagues/students from developed countries are: a more advanced business environment, the availability of multiple sources for learning, more practical experience, student exchange programmes, larger budgets and university reputation. This paper presents an innovative way of active learning for business schools through business case competitions, valuably contributes to gaining skills and knowledge, personal improvement for students and better preparation for their future career.
\end{abstract}

Keywords: The case study competition, higher education, student's perception, internationalisation, Serbia JEL classification: I23, C00, D83

\section{Introduction}

According to the data of the Word Bank Enterprise Survey, based on the sample of 10690 enterprises from 23 Eastern European countries and on the data collected in 2012, one of the most important obstacles for doing business is inadequately educated workforce. According to the same data source, in Serbia, 37.5\% of enterprise representatives reported inadequately educated workforce as an obstacle to their current operations (see more in Mijatovic and Damnjanovic, 2016). The gap between the job market needs and outcomes of higher educational institutions is a challenging topic for a large number of academics and practitioners.

In the areas of management and business higher education, crossing the lines between the corporate and academic world seems to be a crucial task for many business schools. The global and dynamic business environment influences higher education in multiple ways and many business schools are faced with the need to "internationalize" institutional culture and the student experience at university (Altbach and Knight, 2007) in order to prepare students for their future career (Teichler, 2009, Paphitis and Kelland, 2016). As future managers and leaders, students need to develop critical and creative thinking skills (Greenhalgh, 2007).

Apart from globalization and internationalization, changing student expectations and changing employer needs (Casareset al., 2011) rank among key drivers of change in higher education today. Based on the research (Lowden et al., 2011) of the University of Glasgow, employers expect graduates to demonstrate a 
range of skills and attributes that include: teamwork, communication, leadership, critical thinking, problem solving and often managerial abilities. In the knowledge economy, new entrant skills are highly desired by employers, as they are critical to an employee being successful in their work. Under the high influence of technology usage and social media, the key values of the millennial generation are meaningful work and a high salary (Meeker, 2015). A recent study by Rosenbaum et al. (2016) identified that students expect college to provide to them: progress, relevant courses and job contacts.

Recently, there has been a growing interest in providing adequate knowledge and skills in the management field for students included in higher education using the case method as a learning tool (Christensen and Carlile, 2009, Gamble and Jelley, 2014). In a research study (Hawes, 2004) it is pointed out that case solving thinking help students learn about a wide range of companies, industries and problems or opportunities, develop reasoning and logic skills, deal with constructive criticism and learn from it. Leading universities have already created the curricula based on case learning courses and case extracurricular programmes with top talent students with an objective to compete at international case competitions and maintain a strong reputation all around the world.

The main objective of the research presented in this paper is to provide insight into the benefits from being engaged in international case study competitions from the perception of Serbian students. The paper is structured as follows. The next section introduces a literature review related to active teaching methods and case study competitions. The third section provides methodology, while the forth section reports the results. Finally, the fifth section derives discussion based on the results and provides concluding remarks.

\section{Literature Review}

As an active teaching strategy, the case study method was developed by Harvard University as a way to expose business students to 'real' corporate problems(Credleet al., 2009). Erskine (1998) defines case studies as 'a description of a real event, which includes a decision, challenge, opportunity, problem or attitude with which a person or people in an organization are faced. Literature proves that there are two areas in which the case study method can be used in higher education: the classroom and the case competitions. Case based learning is a well-known teaching and learning method that motivates students to learn and bridges the gap between theoretical knowledge and practice (Lee et al., 2016). Therefore, the classroom needs to include active and interactive learning as the basis for developing understanding of core disciplinary concepts, with strong implications for student retention (Crosling et al., 2009.). Finally, the case method allows the students and teachers to learn by doing, which is believed to be one of the best ways to integrate knowledge (Cameron et al., 2012).

However, applying active case learning at a case competition describes an opportunity for undergraduate students to apply concepts they have recently seen in their coursework to 'real world' business problems (Bale et al., 2013). Competitions enable students to deal with the challenge of delivering results under pressure, given an enigmatic real-world business problem (Sachau and Naas, 2010).Case competitions can be used to prepare students for their future professions as the case study method helps students develop managerial skills including: problem solving, critical reasoning, analytical thinking, teamwork skills, confidence and other personal and professional improvements (Umbleet al., 2008, Damnjanovic et al., 2016). A case study competition exposes students to real world experiences, encourages them to take ownership of their learning and helps them assimilate their ideas into theory and practice (Burke et al., 2013). This optimizes learning transfer and shifts learning responsibility to the students to set learning goals and apply effective learning strategies (Corner, 2006, Yueet al., 2016). There are three stages of the learning process for fast tackling cases that helps students achieve superior results. This three step case learning process consists of: individual preparation, small team and large team discussion (Maufefette-Leenders et al., 1999).

Referring to potential employability skills, case study competitions improve teamwork, critical thinking and communication skills, which are the skills that employers require from their new employees (Burke et al., 2013). Case competitions provide an opportunity to make business education meaningful to business students, while providing students with an opportunity to prepare for upcoming career challenges. Lastly, the benefits for managers and companies from case competitions are: recruitment of high achieving students and networking with the organization that provided the case to the faculty (Damnjanovic, 2011). Based on previous research, case competitions have been shown to have multiple benefits for the students who are 
participating; however, one should notice these studies come primarily from developed world countries. Few research efforts have been devoted to the perceptions of international case study competitions in countries that have only recently started to participate in the competitions.

\section{Methodology}

\subsection{Research Questions}

The research work presented in this paper was driven by the following two main research questions (RQs):

RQ1: How do students perceive benefits from being engaged in case study competition?

RQ2:How do students perceive their advantages and disadvantages when compared to colleagues/students from developed countries (higher level universities) being engaged in case study competition?

\subsection{Study Design, Data Collection and Analysis}

Even though the case study competitions have long tradition in business schools in developed countries, studies about effects of the case study competitions are missing. In order to explore perception of effects from being engaged in international case study competitions we needed a knowledge base for future research so the Critical Incident $(\mathrm{Cl})$ technique was chosen. The $\mathrm{Cl}$ technique is a well proven qualitative research approach to collecting and analyzing information about human activities; it is used to reflect reallife experience and provide a knowledge base for further research (Hughes, 2007, p.49). The $\mathrm{Cl}$ technique was developed by John Flanagan during World War II, was best described in his article published in July 1954 in the Psychological Bulletin, where he defined the $\mathrm{Cl}$ technique as "a set of procedures for collecting direct observations of human behavior in such a way as to facilitate their potential usefulness in solving practical problems..." (Flanagan, 1954). An incident means significant instances of a specific human activity as experienced or observed by the research participants (Hughes, 2007, p.50). By recalling and mentioning their experience (in interviews or written statements), an examinee provides evidence of a specific experience which is valuable and important for them. It is possible to have a situation in which some examinees had a specific experience but they failed to mention it; however, in this case that kind of experience was considered as not important, valuable or noteworthy.

Since Flanagan's work, the $\mathrm{Cl}$ technique has evolved and has numerous variations; in our research we followed the method of Johnson and Gustafsson (2000). This method was chosen to avoid any influence on student perception. In the first step we analyzed potential research participants and the context of their experience. We identified 36 participants (20 female and 16 male students or ex-students) that had past experience in active participation in international case study competitions. All research participants have had experience in participating in at least one international case study competition with other teams from the UK, Denmark, Norway, the Netherlands, Portugal, the USA, Canada, Singapore, China, Hong Kong, Thailand, Australia and New Zealand.

In order to better understand there search participants' experience, the structure and process of the international business case competition is elaborated. The structure and process of the international business case competition for undergraduate students are usually as following. Each business school selects a team of four students and one mentor/case advisor (university staff member or a person from practice). Every student, member of the team, needs to be specialized in a different field such as: accounting, economics, engineering, finance, information technology, international business and marketing. A host university invites each team usually based on results from previous years. In a competition, students are provided with one or multiple cases that they have not seen before and are sequestered in a room for preparation for a limited amount of hours (usually 24 or 32 hours). Each team needs to develop a case solution, based on quantitative analysis and a Power Point presentation and present it to a jury consisting of people from industry (top management level and consultants). The jury panel evaluates the teams based on criteria including content, presentation skills and performance under consideration and answer component. Each case competition chooses the top three winning universities and the number of schools who participate varies from 12 to 30 schools (Damnjanovic et al., 2016). 
Data collection was based on the student responses taken in written form. For the research question RQ1, research participants were asked to provide their description about their experience in being engaged in case study competitions. For the research question RQ2, students were asked only one open question - to provide a list of their advantages and disadvantages from being engaged in case study competition when compared to colleagues/students from developed countries.

After collecting and coding critical incidents, content analysis of occurrences of the same or similar critical incidents and sorting was conducted.

\section{Findings}

In this section, the study results are presented and discussed from the perspective of the research questions (see Section research questions).

RQ1: How do students perceive benefits from being engaged in case study competition?

Based on an analysis of critical incidents, 190 critical incidents were identified, and they were classified into 6 categories (Table 1.). The largest number of critical incidents was identified in the area of skills improvement (37\%). In this area, respondents most frequently mentioned benefits of improving the skills of teamwork and analytical thinking. Respondents mentioned teamwork mostly in two contexts: in the context of improving the ability to work with different types of people and in the context of responsibility and sacrifice for common goals.

Table 1: Critical incidents related to benefits from being engaged in case study competition

\begin{tabular}{|l|c|c|c|c|}
\hline Categories of critical incidents & \multicolumn{2}{|c|}{ Total } & $\begin{array}{c}\text { Male } \\
(\mathbf{1 6})\end{array}$ & $\begin{array}{c}\text { Female } \\
(\mathbf{2 0})\end{array}$ \\
\hline & No. & $(\%)$ & No. & No. \\
\hline 1. SKILLS IMPROVEMENT & $\mathbf{7 1}$ & $\mathbf{3 7 . 3}$ & $\mathbf{2 9}$ & $\mathbf{4 2}$ \\
\hline Teamwork skills & 22 & 11.6 & 6 & 16 \\
\hline Work under pressure & 7 & 3.7 & 2 & 5 \\
\hline Presentation skills & 8 & 4.2 & 5 & 3 \\
\hline Analytical way of thinking & 19 & 10.0 & 8 & 11 \\
\hline Other & 15 & 7.9 & 8 & 7 \\
\hline 2. KNOWLEDGE & $\mathbf{3 5}$ & $\mathbf{1 8 . 4}$ & $\mathbf{1 5}$ & $\mathbf{2 0}$ \\
\hline $\begin{array}{l}\text { The application of theoretical knowledge } \\
\text { acquired at university (application of knowledge) }\end{array}$ & 5 & 2.6 & 2 & 3 \\
\hline $\begin{array}{l}\text { Expansion of existing knowledge } \\
\text { (acquisition of new knowledge) }\end{array}$ & 12 & 6.3 & 4 & 8 \\
\hline Expansion of existing knowledge in specific areas & 15 & 7.9 & 6 & 9 \\
\hline Feedback & 3 & 1.6 & 3 & 0 \\
\hline 3. CONTACTS & $\mathbf{3 0}$ & $\mathbf{1 5 . 8}$ & $\mathbf{1 0}$ & $\mathbf{2 0}$ \\
\hline Business contacts, networking & 15 & 7.9 & 6 & 9 \\
\hline Exploring different cultures & 6 & 3.2 & 2 & 4 \\
\hline Finding friends, developing friendship & 9 & 4.7 & 2 & 7 \\
\hline 4. EMPLOYMENT & $\mathbf{2 9}$ & $\mathbf{1 5 . 3}$ & $\mathbf{9}$ & $\mathbf{2 0}$ \\
\hline In the process of selection and recruitment for job & 9 & 4.7 & 3 & 6 \\
\hline At work & 20 & 10.5 & 6 & 14 \\
\hline 5. SELF-REALIZATION & $\mathbf{1 9}$ & $\mathbf{1 0 . 0}$ & $\mathbf{1 1}$ & $\mathbf{8}$ \\
\hline Progression & $\mathbf{2}$ & 1.1 & 2 & 0 \\
\hline A broader understanding & 3 & 1.6 & 3 & 0 \\
\hline Pushing their own limits & 5 & 2.6 & 2 & 3 \\
\hline Finding areas of interest & 3 & 1.6 & 2 & 1 \\
\hline Self confidence & 6 & 3.2 & 2 & 4 \\
\hline 6.THE ROLE OF MENTOR & $\mathbf{6}$ & $\mathbf{3 . 2}$ & $\mathbf{5}$ & $\mathbf{1}$ \\
\hline Total & 190 & 100 & $\mathbf{7 9}$ & 111 \\
\hline
\end{tabular}


In the context of improving the ability to work with different types of people, respondents positively valued the chance to collaborate with colleagues they would not choose to be in the same task with ("This experience has helped me learn how to work with different people"), In the context of responsibility and sacrifice for common goals, respondents reported positive experience (“...it helped me find compromise between the task and the team "). The benefits gained through improved analytical skills are as following: improvement of problem solving skills ("I have learned how to recognize the core of the business problem and choose the best approach to solve it"), stepping out of factual learning ("... from believing that there is only one solution to a problem, to realizing there are plenty of correct solutions to the same problem"); understanding the difference between ideas and solutions ("... I realized that the idea is relevant only if it is applicable and realistic in practice ","l learned how to implement ideas, and not only to create them") and understanding the broader context of the business case ("I developed the ability to see "the broader picture").

From the total number, $18 \%$ of participant responses are associated with the experience of gaining new knowledge. These experiences are systematized into four subgroups: expansion of existing knowledge in general, expansion of existing knowledge in specific areas, the application of theoretical knowledge and feedback. Most of the experiences in this area are related to expanding and acquiring new general and specific knowledge. Thus, it can be concluded that the process of preparing for the case study competition encourages 'continuous learning', 'constantly learning about new things and sharing the knowledge', and business knowledge (acquired during preparations). Most of the respondents (60\%) stated that, through working on the case studies, they learned about different markets, different industries and "how the business world works, in this country as well as globally."

The respondents stated that their involvement in Case Study Competitions helped their self-realization through: progression "The most interesting thing is how I "progressed seamlessly" and "I see a huge change in comparison with two years ago"); a broader understanding ("I expanded my horizons"); pushing their own limits ("When a student learns how to come up with the best possible solution within 24 hours, it teaches him/her that there are no limits", "Allows me to constantly go beyond my limits - in the direction in which I want to develop"); finding areas of interest ("Because of the case competition, I realized what I want to do in my life and what my future career should be") and self-confidence ("It is very important for me that I overcame the fear of speaking in public and because of that I am a step ahead of all other applicants for a certain job position").

Of the total number of identified critical incidents, $17 \%$ are related to networking. The critical incidents are grouped into three subgroups: the establishment of business contacts, making friends and learning about other cultures. Half of the critical incidents in this group relate to the establishment of business contacts. About $30 \%$ of respondents recognized the benefits of meeting, knowing and getting feedback from company representatives that they met during case competitions in jury panels. Respondents perceive business contacts as "priceless", "very important" and "extremely useful" ("International competitions enabled me to create priceless contacts", "I am connected with the extremely talented people, with whom I can cooperate and I did cooperate after college").

Of the total number of identified critical incidents, $15 \%$ refer to the benefits of participation in the case study competition for employment and daily work. Out of 36 respondents, 18 mentioned positive experiences in employment ("I think I initially had the advantage over the other candidates", "During one of the competitions, representatives of the company liked how our team solved the case, so they called us for an internship. A few years later, thanks to that, I got the opportunity to work in the headquarters of one of the 25 largest companies in the world."

Most of these experiences are related to the benefits of finding a good job position. In the area of work benefits most of the experiences are mentioned in the context of an easier adjustment ("I managed to adjust my way of thinking and accessing business problems in a way that employers and companies expect from their employees", "Easier to adapt to business environment and begin to contribute to the company, a specific approach adopted in the case competition ("Business people recognize and value in practice the kind of attitude and experience gained through solving cases", "I'm ready to respond to different challenges, to always be ready to work under pressure and show creativity"). 
RQ2: How do students perceive their advantages and disadvantages when compared to colleagues/students from developed countries being engaged in case study competition?

Based on an analysis of critical incidents, 163 critical incidents were identified, which are related to the perception of advantages of domestic students and 146 that are related to the perception of advantages of students from developed countries (Tables 2 and 3). The perceived advantages of domestic students are seen in the areas of presentation skills, team work skills, creativity, adroitness, broad education multidisciplinary approach and analytical skills. Respondents have especially emphasized seriousness as a very important benefit of the preparation process for a case competition.

From the $\mathrm{Cl}$ analysis, which refers to personal advantages of domestic students, the following areas were identified:

- Presentation skills and structure. The domestic students explain their experiences through three contexts: they emphasize presentation as a tool for 'selling the solution' ("All of us are aware of the importance to pitch the solution in a good way"), the energy during presentations ("We know how to create an impression and stand out from others with our energy", and the appearance and structure of PowerPoint presentations ("Visually, we are great as a team but as good in creating power point slides").

- Preparations for case competitions. Respondents explained their experience through three contexts: the seriousness of preparations, specific mentorship work, and preparations for specific markets. In the category of seriousness of preparations respondents indicate that they seriously prepare themselves for competitions ("We have intense and thorough preparations", "We make great effort during our periods of preparation", "Preparations are very intense and of great importance for success", "We have excellent relationship with mentors and they provide us detail guidelines and valuable feedback", "our mentors help us prepare for specific markets and understand local difference"), but at the same time indicate the feeling of inferiority ("We prepare very seriously because we are aware of our down sides, such as in comparison with native English speakers", "It is difficult to present on a stage where everyone "considers you worse than themselves", "..we have the urge to win and to be acknowledged", "we do not start from the arrogant assumption that we are the best (because of some world-renowned reputation), which makes us work twice as much"). Due to limited resources for competitions, respondents indicate that the teams prepare via the transfer of experiences from colleagues ("we are always analyzing our weaknesses in order to make progress", "We are unpredictable - we are always changing methodology and we are always ready to surprise". "It is important to hear about experiences from older and more experienced competitors").

- Teamwork. Respondents explained they perceived a better connectivity among their team members when compared to others. "We stand out, because we appear as a team", "team spirit and cooperation between team members are very expressed", "most of the time we seem more as a team in comparison to others"), ("we have more direct relationship and we know each other better", "we work very well as a team", "we are not just team members, we are friends, and that is something that does not exist in other teams").

- Creativity. With regards to creativity, respondents refer to innovative solutions ("we like to think outside the box", "we always have creative ideas aligned with trends from the industry").

- Multidisciplinary approach. Respondents explained the perceived benefits of broad education "when we solve the case we have different perspective from management and information technology side among team members, which provides us with an advantage in technological and business synergy"). 
Table 2: Critical incidents related to advantages of Serbian students in comparison with colleagues/students from developed countries

\begin{tabular}{|l|c|c|c|c|}
\hline \multirow{2}{*}{ Category } & \multicolumn{2}{|c|}{ Total } & Male (16) & $\begin{array}{c}\text { Female } \\
(\mathbf{2 0})\end{array}$ \\
\hline & No. & $(\%)$ & No. & No. \\
\hline PRESENTATION & $\mathbf{4 5}$ & $\mathbf{2 7 . 6}$ & $\mathbf{2 0}$ & $\mathbf{2 5}$ \\
\hline Presentation skill in general (sales) & 24 & 14.7 & 11 & 13 \\
\hline Presentation structure & 3 & 1.8 & 2 & 1 \\
\hline Presentation appearance and structure & 6 & 3.7 & 3 & 3 \\
\hline Energy while presenting & 12 & 7.4 & 4 & 8 \\
\hline PREPARATION & $\mathbf{3 0}$ & $\mathbf{1 8 . 4}$ & $\mathbf{1 5}$ & $\mathbf{1 5}$ \\
\hline Seriousness of preparations & 14 & 8.6 & 8 & 6 \\
\hline Mentorship & 9 & 5.5 & 5 & 4 \\
\hline Preparations for a specific market & 7 & 4.3 & 2 & 5 \\
\hline TEAMWORK & $\mathbf{2 7}$ & $\mathbf{1 6 . 6}$ & $\mathbf{1 0}$ & $\mathbf{1 7}$ \\
\hline Team spirit & 14 & 8.6 & 5 & 9 \\
\hline Team structure & 4 & 2.5 & 2 & 2 \\
\hline Team cohesion & 9 & 5.5 & 3 & 6 \\
\hline CREATIVITY - INNOVATIVE SOLUTION & $\mathbf{1 6}$ & $\mathbf{9 . 8}$ & $\mathbf{5}$ & $\mathbf{1 1}$ \\
\hline RESOURCEFULNESS & $\mathbf{1 2}$ & $\mathbf{7 . 4}$ & $\mathbf{5}$ & $\mathbf{7}$ \\
\hline MULTIDISCIPLINARY APPROACH DUE TO & $\mathbf{1 0}$ & $\mathbf{6 . 1}$ & $\mathbf{6}$ & $\mathbf{4}$ \\
\hline BROAD EDUCATION & $\mathbf{7}$ & $\mathbf{4 . 3}$ & $\mathbf{5}$ & $\mathbf{2}$ \\
\hline ANALYTICITY & $\mathbf{1 6}$ & $\mathbf{9 . 7}$ & $\mathbf{5}$ & $\mathbf{1 1}$ \\
\hline OTHER & $\mathbf{1 6 3}$ & $\mathbf{1 0 0}$ & $\mathbf{7 1}$ & $\mathbf{9 2}$ \\
\hline TOTAL & & & & \\
\hline
\end{tabular}

The 146 identified $\mathrm{Cl}$ relating to the perception of the benefits that students from developed countries have, were classified into two groups. The first group refers to the circumstances in which they prepare students and the second refers to the solutions provided in competitions. Key insights from the first group include:

- More advanced business environment. Respondents believe the key benefits of their counterparts from developed countries is knowledge of the business environment in developing countries ("Business environment in which they live is generally more advanced than ours ", "they know better the mechanisms operating in developed countries", "familiar with new trends and technologies first hand because they appear first on their markets").

- The availability of multiple sources for learning. In the second place, by the number of $\mathrm{Cl}$, were available sources that foreign students have in their preparations. Respondents indicated "university knowledge base", "subscriptions to relevant sources of information," "bigger and better database", "better access to quality literature (textbooks, case books ...)" or ("strong alumni network that is available to them", "cooperation with mentors from strategic consulting").

- Better theoretical knowledge. Respondents believe that their colleagues have more opportunities to gain the knowledge they need to solve a case study during regular lectures ("they learn more during their education," "have a knowledge of the basic studies").

- Native speaker. Respondents believe the mother tongue or fluency in English presents a significant advantage especially because of the knowledge of business terminology ("know better business terminology from different industries").

- They have more practical experience. ("The system allows them to work while studying in order to gain more practical knowledge that can be used in solving the cases", "they get a job at the second year of studies").

- Student exchange programs are considered to be a significant advantage of foreign students ("they go on an exchange programme during education and that way they get a broader picture of global business", "have experience in real consulting through internships and trainings).

- Experience in a case study in the classroom. "Have a longer tradition in the study and the use of case methodology", "education system is more based on cases, therefore they have been more familiar with this way of learning") 
- Bigger budgets. Respondents mentioned larger budgets that their universities have at their disposal in two contexts: through increased investment in education and greater opportunities for participating in competitions. ("Financial aspect that some of the schools abroad have cannot be ignored, although I do not think that this is crucial," "It is clear that they have the opportunity to compete more often but no one has an unlimited budget ").

- Reputation of the universities with which they come from ("When you come from a famous university in the world it is not the same ", "We do not start from the arrogant assumption that we are the best (because of some world-renowned reputation), which makes us to work twice as much").

The benefits of the solutions that our colleagues from developed countries present are related to a clear focus ("they are more focused on business logic rather than on presenting solutions"), focus on feasibility, the simplicity of the design ("Down-to-earth solutions", "their methodology is simple - easy to understand") and focus on implementation ("they have much better implementation with less detail but are easier to follow and easier for the jury to understand").

Table 3: Critical incidents related to advantages of colleagues/students from developed countries

\begin{tabular}{|c|c|c|c|c|}
\hline \multirow{2}{*}{ Category } & \multicolumn{2}{|l|}{ Total } & \multirow{2}{*}{$\begin{array}{c}\begin{array}{c}\text { Male } \\
(16)\end{array} \\
\text { No. }\end{array}$} & \multirow{2}{*}{$\begin{array}{c}\begin{array}{c}\text { Female } \\
(20)\end{array} \\
\text { No. }\end{array}$} \\
\hline & No. & (\%) & & \\
\hline More experience in advanced business environment & 16 & 10.9 & 7 & 9 \\
\hline The availability of multiple sources for learning & 15 & 10.2 & 7 & 8 \\
\hline Better theoretical knowledge & 14 & 9.6 & 3 & 11 \\
\hline Native speaker & 14 & 9.6 & 6 & 8 \\
\hline More practical experience & 12 & 8.2 & 4 & 8 \\
\hline Student exchange programs & 11 & 7.5 & 3 & 8 \\
\hline Experience in a case study in the classroom & 10 & 6.9 & 5 & 5 \\
\hline Bigger budgets & 7 & 4.8 & 2 & 5 \\
\hline University reputation & 3 & 2.1 & 2 & 1 \\
\hline Usage of advanced software & 4 & 2.7 & 3 & 1 \\
\hline The features of the solutions they presented (total): & 30 & 20.6 & 10 & 20 \\
\hline \begin{tabular}{|l|l} 
& Clear focus \\
\end{tabular} & 7 & 4.8 & 3 & 4 \\
\hline Focus on finance & 7 & 4.8 & 2 & 5 \\
\hline Simplicity of solutions & 6 & 4.0 & 1 & 5 \\
\hline Better argumentation in the Q\&A sessions & 6 & 4.0 & 0 & 6 \\
\hline Detailed implementations & 4 & 2.7 & 4 & 0 \\
\hline Other & 10 & 6,9 & 4 & 6 \\
\hline Total & 146 & 100 & 56 & 90 \\
\hline
\end{tabular}

\section{Discussion and Conclusion}

The global and dynamic business environment requires new entrant employees ready for immediate start with many companies providing limited time for learning/introduction in the workplace. In the modern business arena business schools are facing increased pressure for achieving competitive advantage, building stronger university reputation that can be built not only with research but also through excellent and creative active teaching at an international level (Oxford Strategy, 2015). This paper is a pilot study and provides insight into a Serbian student perception of their engagement in international case study competitions.

The international case competitions represent a unique learning experience for Serbian students that allow them to apply practical knowledge and skills, increase self-confidence and establish contacts for future jobs. The results from the current study corresponded with the findings from the research work of Kress et al. (2004). This extracurricular activity of student learning is consistent with the previous work that emphasizes the use of case-based learning as a means of encouraging creative thinking (Credle et al, 2009, Menna, 2009) and better understanding a multidisciplinary approach, connection between business and technological perspectives (Yadav et al, 2007). Furthermore, the opportunity to attend international 
case competition has given students a chance to improve the case learning process in all stages: individual preparation, small group and large group discussion (Maufefette-Leenders et al.,1999).

Following the evidence of study by Hawes (2004), the use of experiences from older and more experienced competitors and mentors in an individual preparation phase help students to better understand the case and identify the main issues quickly because students are constrained by time. Good individual preparation demands a high level of hard work during individual assignments and internship attempts to provoke students who compete at case competitions to present new ways of thinking based on practice knowledge background, Maenette and Benham (1996) which was identified as an advantage of developed countries.

Also, better access to information and familiarity with multicultural environment through international student exchange provide students from developed countries with advantages in individual thinking in business logic field referring to study from Croatia, Jelenc (2011). Students from developed countries (leading universities) have a better perception about strategic recommendation what is feasible on the market. Moreover, after individual preparation there is the second phase of case learning where each team discuss together, Burko (2015). Having an excellent team building skills is an advantage for Serbian students due to the fact that this is a cultural characteristic of Eastern Europe region, which is aligned with the results of the previous study from Serbia and Croatia. (Damnjanovic and Dlacic, 2015).

Our findings showed that the important advantage for better learning performance of Serbian students is the connection of the first and second stages: individual effort preparation is a precondition for successful small group discussion. In that context our results are similar to the findings of Flynn and Klein (2001). Working in team of four students and discussion in small groups for case competition provides possibility to encourage debate, brainstorming session and allow them to construct new creative ideas. Additionally, a large team discussion as the third phase of case learning at case competition provides a students team with a possibility for learning, comparing different approaches of presentation skills delivery to jury panel. Students should develop cross cultural awareness skills considering a variety and diversity of student ideas from Europe, Asia, North America and Australia. Respondents believed they were better in presentation and delivery in comparison with other students from leading universities. This is probably because Serbian students are not native speakers and they prepare more intensely for presentation and for how to sell the recommendations to target audience.

Our findings show that students perceive their engagement in international case study competitions as a very positive and life changing experience. Key benefits are seen in the improvement of managerial and employment skills: presentation skills, teamwork skills, under pressure skills and analytical thinking. The majority of the students pointed out an important effect of their engagement in international case study competitions as - stepping out of factual learning and understanding the broader context. Learning is moved from memorization of numerous facts to the practical application of theories, concepts and techniques to real problems. In a broad sense our findings are compliant with those of (Meeker, 2015) that the millennial generation values motivation achieved by engaging in meaningful work. Our results are compliant with research study of Credle et al. (2009) that perceived that the benefits of the case competition are the possibility of networking, and opportunities such as student internships or offers of permanent employment.

On the other side, international case study competitions can be seen as an area of exchange of experience in the teaching and learning practice. Teachers should encourage active case learning and give students feedback and be open to varying levels of talent and learning abilities (Latusek, 2016). Our findings explain, experience with case study competitions shifts student perception of learning, from teachers 'providing knowledge' to students 'taking responsibility for their learning'. Almost all examinees mentioned more advanced business environments, the availability of more sources for learning (knowledge basis, university online libraries and databases) and bigger budget as key advantages of their colleagues from developed countries. Other disadvantages as a lower level university are that leading universities globally have focus on international dimension (provide undergraduate programmes in the English language for international students and international student programme exchange). Furthermore, their formal education system is more based on cases and has better theoretical knowledge (case educational program). Also, leading schools have more practical experience because of three months of student internships during the educational study process (better practical knowledge). These outcomes: more adequate on line learning materials (database and software), launching international program, more cases in formal education and better practical knowledge through internships should serve as directions for improvement for business schools in Serbia as a representative from Eastern Europe region.

The limitations of this study include the number of participants who attend an international case competition from one business school. Other limitations include only the opinion from the student perspective. A future study may explore opinions from the mentor side and a larger international sample. Future research can focus on the comparison of the students' and mentors' perceptions of case competition benefits. 


\section{REFERENCES}

[1] Altbach, P.G. \& Knight., J. (2007). The Internationalization of Higher Education: Motivations and Realities. Journal of Studies in International Education, 11(3/4), 290-305. DOI: 10.1177/1028315307303542

[2] Bale, J.M.,Senteza, J.\& T.A. White. (2013). A Model for Running an Undergraduate Business-Focused Case Competition, International Research Journal of Applied Finance, ISSN 2229 - 6891.1-16. Retrieved from: https://irjaf.com/uploads/IRJAF_case_studies_in_finance_and_accounting_Vol_ll.pdf

[3] Burke, M.G. Carter J.D. \& W.A.Hughey. (2013). The use of case study competitions to prepare students for the world of work.Industry \& Higher Education, 27(3), 157-162. DOI: 10.5367/ihe.2013.0156

[4] Burko, L. M. (2015). Using the case study method in teaching college physics. The Physics Teacher. 54(7), 413-415. DOI: 10.1119/1.4962777

[5] Cameron, AF. Trudel, MC. Titah, R.\&PM. Léger. (2012). The Live Teaching Case: A New IS Method and its Application. Journal of Information Technology Education Research, 11, 27-41., Retrieved from: http://www.jite.org/documents/Vol11/JITEv11p027-042Cameron1064.pdf

[6] Casares, J. Dickson, D.A. Hannigan, T., Hinton, J. \& Phelps, A. (2011). The Future of Teaching and Learning in Higher Education Rochester Institute of Technology, 1-31., Retrieved 12 June 2016, from: https://www.rit.edu/academicaffairs/sites/rit.edu.academicaffairs/files/docs/future_of_teaching_and_lear ning_reportv13.pdf

[7] Christensen, C. M., \& Carlile, P.R. (2009) Course research: Using the Case Method to Build and Teach Management Theory, Retrieved 4 March 2016 from: http://www.thefgi.net/wpcontent/uploads/2010/09/Theory-Building-Paper.pdf

[8] Corner, P.D., Bowden, S., Clark, D., Collins, E., Gibb. J., Kearins, K. \& Pavlovich, K.(2006). Grounded learning from a strategy case competition Journal of Management Education, 30, 431454.DOI:10.1177/1052562905277789

[9] Credle, S.H., Beale, P.L .\& Maheshwari, S. (2009). The Use Of Case Analysis Training and Competitions To Assure Learning And School-Wide Quality, Business Education \& Accreditation, 1(1), 29-44. DOI: 10.12691/jbe-5-1-2

[10] Crosling, G., Heagney M \& Liz, T. (2009). Improving student retention in higher education.Australian Universities Review, $51(2), 9$-19.

[11] Damnjanovic, V. (2011). Marketing in Practice Applying the Case Studym Method: Belgrade, Faculty of Organizational Sciences

[12] Damnjanovic, V. \& Dlacic, J. (2015). Perceived Students' Benefits Of Case Study Learning In Marketing: Comparative Analysis Of Croatia And Serbia, 24th CROMAR Congress. Proceeding Marketing. Theory and Practice- Building Bridges and Fostering Collaboration, Split, Croatian Marketing Association

[13] Damnjanovic, V., Proud, B., \& Ruangwanit, N. (2016).Perceived benefits and issues of student learning in business case competition - Comparison study of Serbia, Australia and Thailand.Athens Journal of Education, forthcoming issue, Retrieved 23 May 2017 from https://www.athensjournals.gr/education/2017-1-X-Y Damnjanovic.pdf

[14] Erskine, J.A., Leenders, M.R., \& Mauffette-Leenders, L.A. (1998). Teaching with cases. London: Ivey Publishing.

[15] Flanagan, J.C. (1954). The Critical Incident Technique, Psychological Bulletin, 51(4), Retrieved 6 July 2017 from: https://www.apa.org/pubs/databases/psycinfo/cit-article.pdf

[16] Flynn, A. E. \& Klein, J.D. (2001). The influence of discussion groups in a case-based learning environment. Educational Technology Research and Development, 49(3), 7186.DOI:10.1007/BF02504916.

[17] Gamble, E.N. \& Jelley, R.B. (2014). The Case for Competition: Learning About Evidence-Based Management Through Case Competition, Academy of Management Learning \& Education, 2014, 13(3), 433-445. DOI: 10.5465/amle.2013.0187

[18] Girgin, K.Z.\& Stevens, D.D. (2005). Bridging in-class participation with innovative instruction: Use and implications in a Turkish university classroom. Innovations in Education and Teaching International, 42,93-106., DOI:10.1080/14703290500049059

[19] Greenhalgh, A.M. (2007). Case method teaching as science and art: a metaphoric approach and curricular application. Journal of Management Education, 31(2), 181-194.DOI: $10.1177 / 1052562906291306$

[20] Hawes, J.M. (2004). Teaching Is Not Telling: The Case Method As A Form Of Interactive Learning, Journal for Advancement of Marketing Education, 5, 47-54., Retrieved 5 April 2016, from: http://www.mmaglobal.org/publications/JAME/JAME-Issues/JAME-2004-Vol05-Issue1/JAME-2004Vol05-Issue1-Hawes-pp47-54.pdf 
[21] Hughes, H.E. (2007) Critical incident technique. In Lipu, Suzanne, Williamson, Kirsty, \& Lloyd, Annemaree (Eds.) Exploring methods in information literacy research. Centre for Information Studies, Charles Sturt University, Wagga Wagga, N.S.W., pp. 49-66.

[22] International Trends in Higher Education. (2015). University of Oxford International Strategy Office, Retrieved 1 March 2017, from: https://www.ox.ac.uk/sites/files/oxford/International\%20Trends\%20in\%20Higher\%20Education\%202015.pdf

[23] Jelenc, L. (2011).The case study method, Higher Education in South Eastern Europe In: University Economy Partnerships for Enhancing Knowledge Transfer, World University Service, Austria, 38-47. Retrieved 7 May 2011 from: http://www.wus-austria.org/files/docs/manual5_endps.pdf

[24] Johnson, M.D. \& Gustafsson, A. (2000). Improving customer satisfaction, loyalty and profit: an integrated measurement and management system. San Francisco, CA: Jossey-Bass.

[25] Kress, J. S., Norris, J.A, Schoenholz, D.A. Elias, M.J. \& Seigleet, P. (2004). Bringing Together Educational Standards and Social and Emotional Learning: Making the Case for Educators, American Journal of Education, 111(1), 68-89. DOI:10.1086/424720

[26] Latusek, D. (2016). Case Studies as a Teaching Tool in Management Education,p.16, Hershey PA, IGIGlobal. DOI: 10.4018/978-1-5225-0770-3.

[27] Lee, S.J., Ngampornchai, A., Trail-Constant, T., Adril, A. \& Srinivasam,S. (2016). Does a case-based online group project increase students' satisfaction with interaction in online courses?Active Learning in Higher Education, 17(3), 249-260. DOI:10.1177/1469787416654800

[28] Lowden, K., Hall, S., Elliot, D. \& J. Lewin. (2011). Employers' perceptions of the employability skills of new graduates.Project Report. Edge Foundation, London, UK.

[29] Maenette Benham, K.P. (1996). The Practitioner-Scholars' View Of School Change: A Case Based Approach To Teaching And Learning, Teaching \& Teacher Education, 12(2),121- 135. https://eric.ed.gov/?id=EJ528651

[30] Maufefette-Leenders, L. A., Erskine, J. A. \& Leenders, M. R., (1999).Learning with cases, Richard Ivey School of Business, The University of Western Ontario, Ontario.

[31] Meeker, M. (2015).Internet Trends 2015 - Code Conference.KPCBKleiner Perkins Caufield\& Byers. 2015, Retrieved 5 June 2016 from: http://www.kpcb.com/internet-trends

[32] Menna, A. (2010). The business case method: an examination of a 2009 case competition. Management in Education, 24(2), 74-79. DOI:10.1177/0892020610363094

[33] Mijatovic, I. \& Damnjanovic, V. (2016), Innovative Strategies For New Competence Development Bringing The Real World In Higher Education, Paper presented at the Symposium proceedings - XV International symposium Symorg 2016: Reshaping the Future Through Sustainable Business Development and Entrepreneurship, Zlatibor, Faculty of Organizational Sciences, University of Belgrade

[34] Paphitis, S.A. \& L. Kelland.(2016).The University As A Site For Transformation: Developing Civic minded Graduates At South African Institutions Through An Epistemic Shift In Institutional Culture, Education as Change, 20(2), 184-203. DOI: 10.17159/1947-9417/2016/906.

[35] Parkinson, J. (2008). Case Studies And How They Are Used, Journal of Business Case Studies 4(12):16.Retrieved from:https://www.cluteinstitute.com/ojs/index.php/JBCS/article/view/4821/4913

[36] Rosenbaum, J.E., Becker, K.I., Cepa, K.A. \& Zapata-Giet, C.E. (2016). Turning the Question Around: Do Colleges Fail to Meet Students' Expectations? Research in Higher Education. 57, 519543.DOI:10.1007/s11162-015-9398-3

[37] Sachau, DA \& Nass, P. (2010). The Consulting Challenge: A Case Competition, Journal of Management Education, 34(4):605- 631. DOI:10.1177/1052562909358556

[38] Teichler, U. (2009). Internationalisation of Higher Education: European Experiences. Asia Pacific Educational Review. 10,93-106. DOI:10.1007/s12564-009-9002-7

[39] Umble, E.J., Umble, M .\& Artz, K. (2008). Enhancing Undergraduates' Capabilities Through Team-Based Competitions: The Edward Jones Challenge. Decision Sciences Journal of Innovative Education, 6(1), 1-27. DOI:10.1111/j.1540-4609.2007.00164.x

[40] Yadav, A., Lundeberg, M.A., DeSchryver, M., Dirkin, K. H., Schiller, N., Maier, K., \& CF. Herreid, (2007). Teaching science with case studies: A survey of faculty perceptions on the benefits and challenges of using cases. Journal of College Science Teaching, 37(1), 34-38., Retrieved from https://eric.ed.gov/?id=EJ774281

[41] Yue, Z.A., Wing, A.B., \& Yates, G.B.(2016). University students' self-control and self-regulated learning in a blended course. Internet and Higher Education, 30, 54-62.DOI: 10.1016/j.iheduc.2016.04.001 


\section{$1 / 1 / 1 / 1 / 1 / 1 / 1 / 1 / 1 / 1 / 1 / 1 / 1 / 1 / 1 / /$ abouthe euthor}

Vesna Damnjanović

University of Belgrade, Faculty of Organizational Sciences damnjanovic.vesna@fon.bg.ac.rs

Vesna Damnjanović is an associate professor at the Marketing Department of the Faculty of Organizational Sciences, University of Belgrade. She gained her Professional Postgraduate Diploma in Marketing at the Chartered Institute of Marketing in the United Kingdom. Her research focuses on: Education using Case Study Method, Active Learning and Teaching with Cases, Marketing and Sales, Destination Branding. She is the founder and Managing Director of Belgrade Business International Case Competition - BBICC - top 12 business case competitions in the world and coach for many winning student teams in case competitions at a global level.

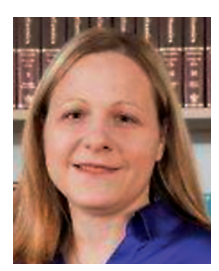

Ivana Mijatović University of Belgrade, Faculty of Organizational Sciences mijatovic.ivana@fon.bg.ac.rs

Ivana Mijatović is an associate professor at the Faculty of Organizational Sciences, University of Belgrade. She earned her B.Sc. in Mechanical Engineering at the Faculty of Mechanical Engineering, University of Belgrade, har M.Sc. and Ph.D. at the Faculty of

Organizational Sciences, University of Belgrade. During a large part of her academic career, she has focused on quality management and standardization. She is a passionate teacher; at bachelor studies she teaches Standardization, Quality

Engineering and Quality Planning, at master and $\mathrm{PhD}$ studies she teaches Standardization and ICT Standardization. She serves on the boards of the European Academy for Standardization (EURAS) and Balkan Coordination Committee for

Standardization, Protypes and Quality (BCC). Her current academic work addresses the issue of standardization, education about standardization, teaching quality and quality aspects of technology enhanced learning.

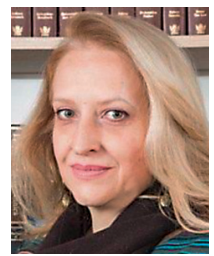

